\title{
Polycrystalline thin Films FY 1992 Project Report
}

NRET/TP-413-5270

DE93 000070

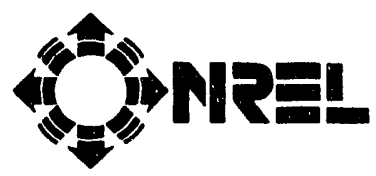

National Renewable Energy Laboratory 1617 Cole Boulevard Golden, Colorado 80401-3393

A Division of Midwest Research Institute Operated for the U.S. Department of Energy under Contract No. DE-AC02-83CH10093

January 1993

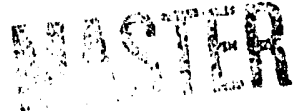




\section{NOTICE}

This report was prepared as an account of work sponsored by an agency of the United States government. Neither the United States government nor any agency thereof, nor any of their employees, makes any warranty, express or implied, or assumes any legal liability or responsibility for the accuracy, completeness, or usefulness of any information, apparatus, product, or process disclosed, or represents that its use would not infringe privately owned rights. Reference herein to any specific commercial product, process, or service by trade name, trademark, manufacturer, or otherwise does not necessarily constitute or imply its endorsement, recommendation, or favoring by the United States government or any agency thereof. The views and opinions of authors expressed herein do not necessarily state or reflect those of the United States govemment or any agency thereof.

Printed in the United States of America

Available from:

National Technical Information Service

U.S. Department of Commerce

5285 Port Royal Road

Springfield, VA 22161

Price: Microfiche A01

Printed Copy $\mathrm{AOS}$

Codes are used for pricing all publications. The code is determined by the number of pages in the publication. Information pertaining to the pricing codes can be found in the current issue of the following publications which are generally available in most libraries: Energy Research Abstracts (ERA); Government Reports Announcements and Index. (GRA and I); Scientific and Technical Abstract Reports (STAR); and publication NTIS-PR-360 available from NTIS at the above address. 


\title{
POLYCRYSTALLINE THIN FILMS FY92 PROJECT REPORT
}

\author{
K. Zweibel, Project Manager (editor)
}

\section{INTRODUCTION}

What are polycrystalline thin films and why do we focus about $\$ 10$ million of Federal funds annually on their development?

The purpose of the DOE/NREL PV Program is to facilitate the development of PV that can be used on a large enough scale to produce a significant amount of energy in the US and worldwide. The PV technologies under the Polycrystalline Thin Film umbrella are among the most exciting 'next-generation' options for achieving this goal. Over the last fifteen years, cell-level progress has been steady, with laboratory cell efficiencies reaching levels (15\% to $16 \%$ ) unheard of for thin films (Figure 1). This progress, combined with the potentially inexpensive methods used to make these cells, has attracted significant commercial interest from US and intemational companies. Among the companies now committed to commercializing polycrystalline thin films are AstroPower, BP Solar, Siemens Solar, Matsushita, Solar Cells Inc., Golden Photon, Energy PV, Intemational Solar Electric Technologies, Martin Marietta, and Solarex. The NREL/DOE program is designed to support the efforts of US companies through cost-shared subcontracts (called 'govemment/industry partnerships') that we manage and fund (see Table 1), and through collaborative technology development work between industry, universities, and our laboratory. About $60 \%$ of our Project funding is devoted to subcontracts with industry and with US universities.

During the last few years, much of the focus of our Project has switched from cell-level issues to issues conceming larger-area devices (submodules and modules). The companies that are developing polycrystalline thin films have all moved into a precommercial stage in which their concerns are process and manufacturability related. Table 2 is a summary of the state-of-the-art in submodule and module efficiencies for the key polycrystalline thin films. These modules represent the base upon which commercial products will be developed. In many cases, the efficiences of the modules in Table 2 far surpass those of any other thin film at those sizes.

As represented by the trends in Figure 1 (cell efficiencies) and the accomplishments of Table 2 (module sizes/efficiencies), the Polycrystalline Thin Films Project has a history of success. We believe that we are on the right path towards making new PV technologies a commercial reality. This report summarizes the activities and results of our last fiscal year, FY1992 (October 1991 - September 1992). It is organized by our main activities: our subcontracts program and our in-house technology development efforts in copper indium diselenide, cadmium telluride, and in materials and device characterization and analysis.

\section{POLYCRYSTALLINE THIN FIMM SUBCONTRACTS}

The polycrystalline thin film subcontract task supports research and development in three thin film technologies, namely, cadmium telluride (CdTe), copper indium diselenide (CIS, $\mathrm{CuInSe}_{2}$ ), and silicon-film (Si-Film) on low-cost substrates. The subcontracted research is divided into two areas, government/industry partnerships and university research. There 


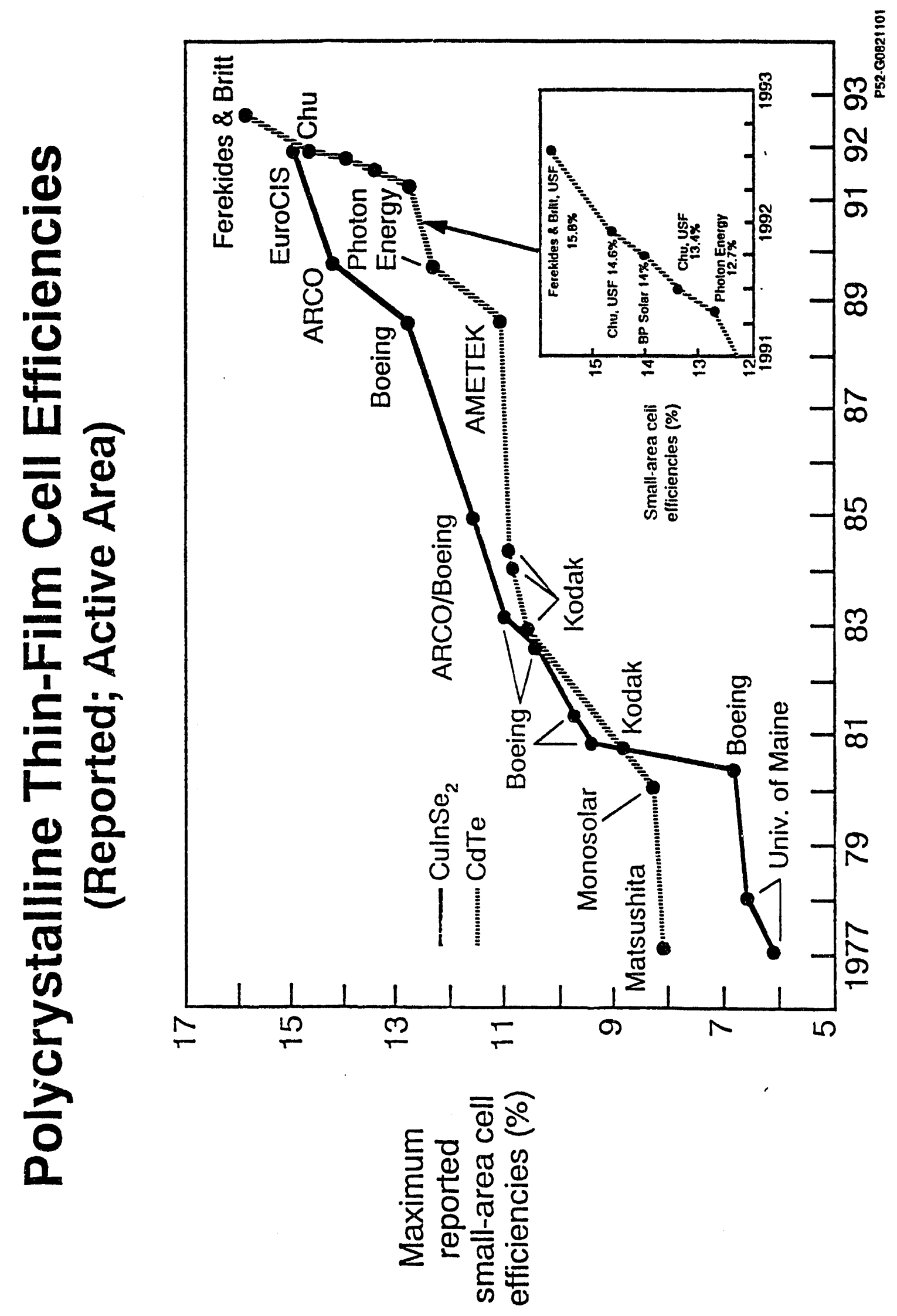




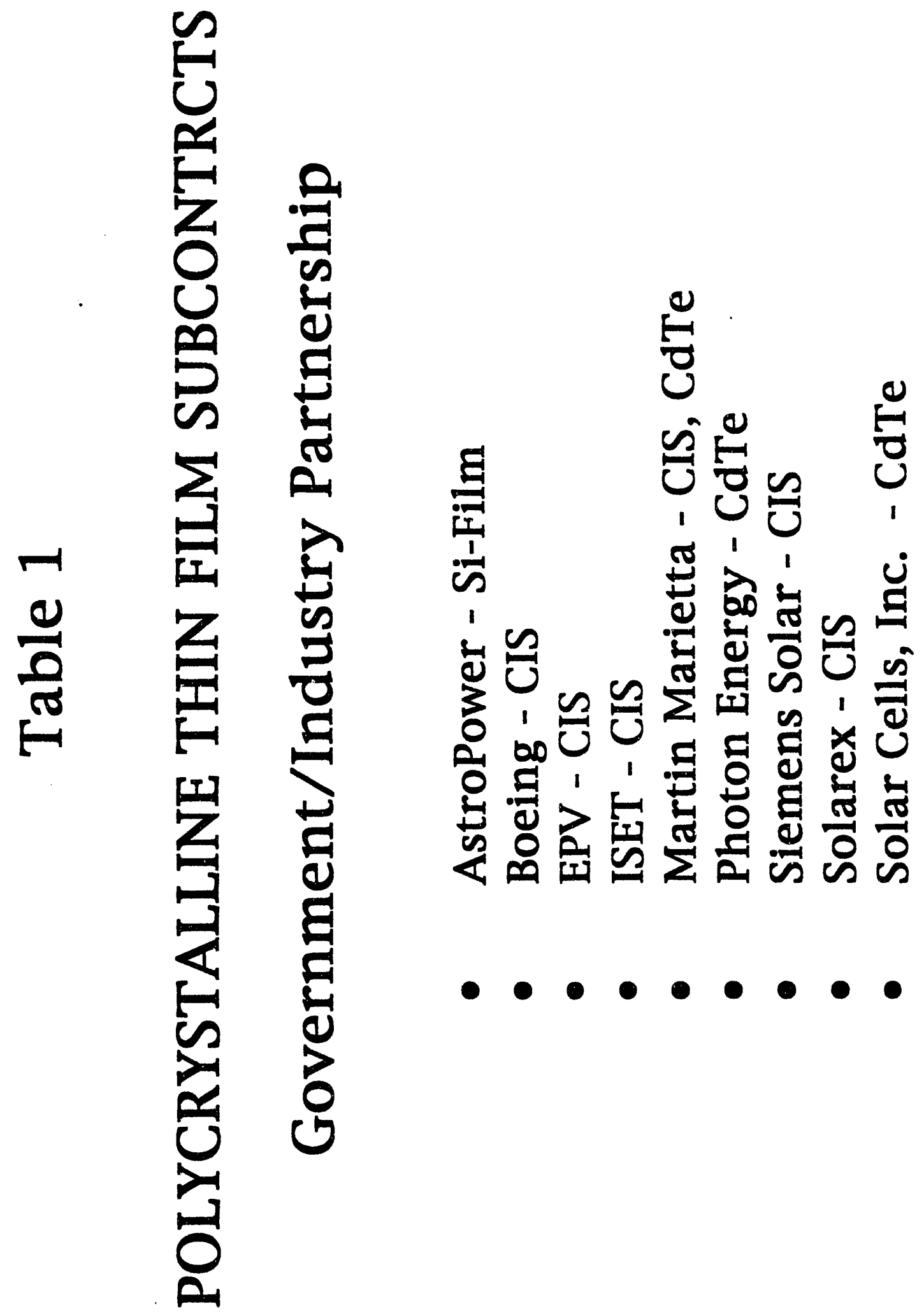




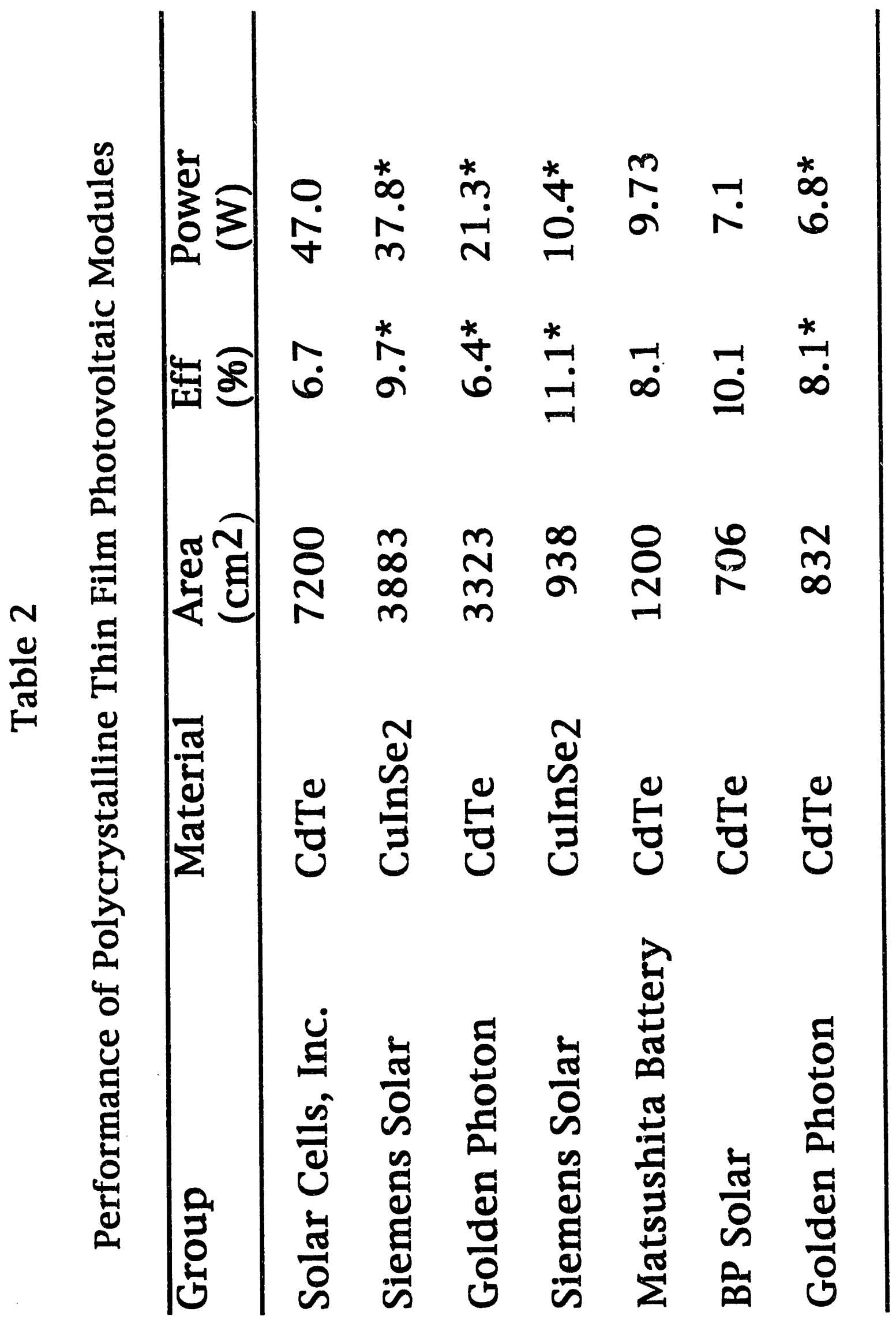


were nine industrial groups supported during FY92, including multinationals and small businesses, and ten university groups. Six of the university groups were winners in a recently concluded Letter of Interest (LOI) competition. Two university groups were selected as the first to be named University Centers of Excellence for Photovoltaic Research and Education by the Department of Energy.

\section{Government/Industry Partnerships}

As part of our government/industry partnership programs, nine groups were actively involved in the R\&D of polycrystalline thin films. This included both multinationals and small businesses. There were six groups working on CIS, two in CdTe and one in SiFilm. The various industrial subcontractors were given in Table 1, and the status of CIS and $\mathrm{CdTe}$ module performance was given in Table 2.

Substantial technical progress occurred in the area of thin film CdTe technology. Large area module efficiencies were improved by two groups. Photon Energy, Inc. (PEI) of El Paso, TX, improved the performance of their 4- $\mathrm{ft}^{2}$ thin film CdTe module to an aperturearea efficiency of $6.3 \%$ with a power output of $21 \mathrm{~W}$ (verified by NREL). Their modules are undergoing various reliability tests at PEI and NREL using several encapsulation schemes. The most effective encapsulation thus far has been glass-to-glass packaging. Further improvements are still needed to assure long-term outdoor performance.

More dramatic progress was made by Solar Cells, Inc. (SCI) of Toledo, OH. In little over a year after becoming one of our industrial partners, an $8-\mathrm{ft}^{2}$ thin film CdTe module with a reported aperture-area efficiency of $6.7 \%$ and a power output of $47 \mathrm{~W}$ was fabricated. SCI uses an extremely rapid deposition method in which the semiconductor layers (CdS, CdTe) are deposited over large areas in one minute. This could significantly reduce manufacturing costs. SCI is aggressively pursuing several encapsulation schemes for their thin film modules. Their near-term plans are to use a glass-to-glass encapsulant scheme, while long-term plans are to use a spray-on encapsulant to reduce the unit module cost by eliminating one piece of glass. SCI will be delivering a $1 \mathrm{~kW}$ system to NREL in FY93 as part of the PVUSA EMT-3 project.

Additionally, the thin film CdTe industrial infrastructure was bolstered by the entry of another multinational. On September 19, 1992, Adolph Coors Company, through its subsidiary Golden Technologies, purchased Photon Energy, Inc. The new company, Golden Photon, is headquartered in Golden, CO. New deposition equipment is being added to their facilities in El Paso, TX. Golden Photon expects to enter the market with a selling price (not manufacturing cost) of $\$ 3.00$ to $\$ 3.50$ per watt, with further price reductions as manufacturing capacities are increased to $10 \mathrm{MW}$ in Golden, CO by 1996.

The progress in thin film CIS technology has been mixed. Siemens Solar Inc. (SSI), the technology leader, faltered in its effort toward CIS commercialization when it canceled delivery of PVUSA modules. Their recent focus has been on their single-crystal silicon business. However, a 4- $\mathrm{ft}^{2}$ thin film CIS module with an aperture-area efficiency of $9.7 \%$ and a power output of $37.8 \mathrm{~W}$ has been verified by NREL. SSI published data showing 
that their average yield peaks at an aperture-area efficiency of $8 \%(33 \mathrm{~W})$. To put this number in perspective, all a-Si commercial modules are less that $6 \%$ efficient (APS, Solarex, Siemens Solar-Europe, USSC). Stability data on thin film CIS modules tested outdoors remains encouraging. Two $1-\mathrm{ft}^{2}$ thin film CIS modules being tested outdoors at NREL show almost no change in performance after four years of testing, while several 4- $\mathrm{ft}^{2}$ CIS modules also being tested at NREL for about a year are unchanged.

ISET has fabricated their first thin film CIS prototype submodules with reported power outputs in the range of 2.5 to $4.0 \mathrm{~W}$. The submodules were monolithically integrated using laser and mechanical scribing. More importantly, ISET has reached an active-area efficiency of $11 \%$ for small area devices using a nonvacuum method of depositing Cu-In. This proprietary technique is a relatively inexpensive method as compared to the conventional sputtering technique and could turn out to be one of the seminal technical achievements of the year if it is followed with prototype module development and manufacturing.

We have several other industrial partners. Martin Marietta (MM) has successfully installed equipment capable of handling 1- $\mathrm{ft}^{2}$ glass substrates. An innovative technique known as rotating cylindrical magnetron sputtering is being used to deposit the precursor $\mathrm{Cu}$-In. Small cells with total-area efficiencies near $8.5 \%$ have been fabricated thus far. MM has successfully leveraged the DOE/NREL subcontract to obtain other sources of funding. Solarex has achieved on active-area efficiency of $10.2 \%$ for a small-area cell and has made some early prototype submodules. In their process, the $\mathrm{Cu}$-In are deposited by sputtering followed by Se deposition by evaporation. Stoichiometric CIS is formed after a heat treatment in nitrogen at $400 \mathrm{C}$. Energy Photovoltaics (EPV) has fabricated a thin film CIS solar cell with an efficiency of 9.2\%. Like Solarex, EPV has made some early prototype thin film CIS modules up to $1-\mathrm{ft}^{2}$. Boeing, which was involved in cell research, has fabricated the world's highest total-area efficiency CIS-based cell (13.7\%) using CIGS (verified by NREL). AstroPower has been limited in their device performance by the inclusion of impurities both from the ceramic substrates and silicon feedstocks. Typical diffusion lengths are about $10 \mu \mathrm{m}$.

\section{University Research}

1992 has been an important year for progress in polycrystalline thin film solar cell efficiencies. Much of our groundbreaking work was done by universities. New world record efficiencies were obtained for thin film CdTe solar cells (two 15.8\% solar cells made at the University of South Florida, USF) as well as for thin film CIS solar cells (14.8\% active-area efficiency by the Euro-CIS university consortium) ${ }^{1}$. Very promising results were also obtained with quaternary CIS derived compounds, specifically sulphur (a reported $15.2 \%$ active area efficiency by the Euro-CIS university consortium) $)^{1}$, and gallium alloys (14.3\% active area efficiency, Boeing). Two university groups, namely,

1

Not NREL funded. 
Institute of Energy Conversion (IEC) at the University of Delaware and Georgia Institute of Technology (GIT), were declared "University Centers of Excellence for Photovoltaic Research and Education" by J. Michael Davis, Assistant Secretary, Conversation and Renewable Energy, Department of Energy.

It is of interest to note that fundamental research institutions themselves contributed a great deal towards achieving new efficiency records and, in many instances, completely fabricated high efficiency devices without the help of commercial companies. A number of relatively small university groups are experimentally equipped to prepare state-of-theart devices. Relatively little is known about the material properties of the poly-thin film materials. NREL, at the end of FY92, has ten university subcontracts in force to (1) achieve cells with even higher efficiencies, (2) better characterize the layers needed for the fabrication of such cells, (3) better understand the mechanisms providing opportunities for improved cell performance through measurements and computer modeling and simulations, and (4) investigate alternate methods of material preparation of these materials.

In the second half of 1991, 35 responses to a Letter of Interest "University Research on Polycrystalline Thin Film Photovoltaics" issued by NREL were evaluated and ranked. In FY92, six 3-year phased subcontracts were subsequently awarded. In addition, NREL funded four additional fundamental subcontracts under its Polycrystalline Thin-Film PV Program. Of these ten subcontracts, 2 groups focus on optimization of thin film CdTe solar cells and materials, 3 groups focus on thin film CIS cells and materials, 3 groups work with both types of cells and materials, and 2 groups provide standardized cell analyses and computer modeling for both types of solar cells. Table 3 lists these individual groups and indicates the specific issues addressed under the subcontracts.

Presently, various thin-film deposition techniques are used to prepare high-efficiency solar cells with CdTe and CIS, e.g., sputtering, co-evaporation, close-spaced sublimation, rapid thermal processing, chemical solution growth, spray deposition, and screen printing. Some of these techniques are more easily scalable than others. Both thin film CdTe and CIS solar cells commonly use $\mathrm{CdS}$ as the heterojunction partner. The highest efficiencies to date were achieved in the following configurations: glass $/ \mathrm{SnO}_{2} / \mathrm{CdS} / \mathrm{CdTe} / \mathrm{doped}$ graphite paste, where the $\mathrm{CdTe}$ is deposited by close-space sublimation, and glass/Mo/CIS (graded $\mathrm{Cu}$ content)/CdS/ZnO (double layer), where the CIS layer was produced by coevaporation. It may be of interest to note that both types of cells used CdS layers deposited from a chemical solution. Cell optimization requires that the CdS layer be kept as thin as possible. This has not only resulted in higher short-circuit current densities (which are expected because optical absurption losses in the CdS are minimized) but also in higher open-circuit voltages for such solar cells (the mechanism for higher voltages is not understood). However, the absorber-layer deposition process does not appear paramount for the achievement of high efficiencies; and for both materials a variety of deposition techniques (and combinations thereof in the fabrication of a completed cell) have resulted in cells with efficiencies $>10 \%$.

It is of some value to identify which mechanisms (e.g., junction-recombination, 


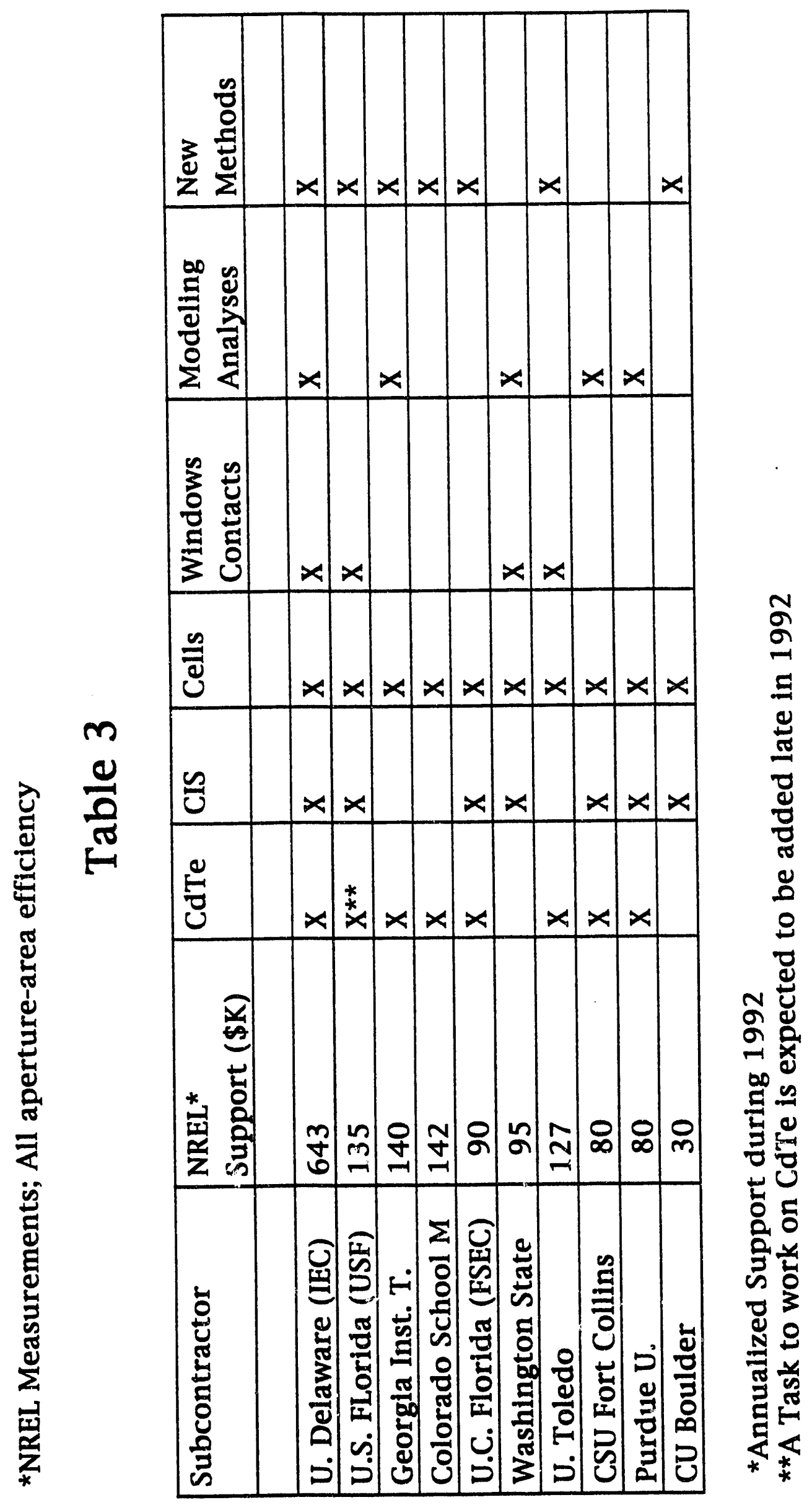


recombination in the absorber, incomplete collection limited by transport properties and/or non-optimized electric field distributions) truly account for the losses in each cell and cause non-ideal performance. The identification of such mechanisms is impeded by (1) lack of knowledge of the electronic properties of each layer, (2) ambiguity of solar cell models requiring many input parameters which are known only within some uncertainty, and (3) the possibility of interdiffusion when different layers are deposited on top of each other during cell fabrication. Especially the performance of thin film CdTe solar cells can be often substantially improved by exposing these cells to post-deposition "treatments" (e.g., a $400 \mathrm{C}$ anneal step in an oxygen acmosphere after the cell was dipped into a $\mathrm{CdCl}$ solution). Only crude speculative models have been proposed to-date to describe the effects of such treatments. All NREL subcontractors, guided by the quest to prepare high-efficiency solar cells, are actively analyzing these phenomena to be able to achieve better quantitative understanding of the electronic properties of their devices. Such improved understanding is critical to overcome problems that are encountered when cell fabrication processes are scaled-up to produce large-area PV modules with high performance and high production yields.

The experimental work of most of our fundamental subcontractors can largely be characterized as being driven by material preparation efforts. In the case of CIS, it is realized that the co-evaporation method, which has yielded cells with high conversion efficiency, may not be ideal because of scale-up difficulties. The other method of sputterdepositing a $\mathrm{Cu}$-In precursor and then "selenizing" the precursor with hydrogen selenide gas may limit production rates (selenization requires time) and involves highly toxic $\mathrm{H}_{2} \mathrm{Se}$ gas. A comparison of different selenization processes was carried out at IEC at the University of Delaware. The other groups use $\mathrm{Cu}$-In or CIS precursors prepared by physical vapor deposition methods, which are later reacted (by annealing) into CIS. One group (CU-Boulder) is investigating the use of rapid thermal processing for this purpose. All research groups prepare actual solar cells, sometimes in collaborative efforts. At the same time, the research groups have various material characterization efforts available to them which should lead to better characterization of the electronic properties of the layers produced, and a correlation with solar cell parameters. Another specific topic for thin film CIS solar cells is an attempt to replace the CdS emitter, because of the following benefits: (1) market related issues associated with cadmium, (2) possible elimination of a layer or process step, and (3) possible enhancements of the open-circuit voltage. Washington State University (with help from Siemens Solar and ISET) is investigating ZnSe-based window layers with some early success.

Several universities are engaged in thin film CdTe research. Close-snaced sublimation and laser ablation deposition are carried out at USF and University of Toledo, respectively. MOCVD deposition and rapid thermal annealing are used at GIT. Physical vapor deposition methods are used at IEC and at FSEC. Colorado School of Mines pursues deposition from chemical electrolytes. Again, all subcontractors have or will fabricate completed solar cells, sometimes in collaborative efforts. They apply their specialized material characterization capabilities to correlate material parameters and device performance. One area of attention is to identify the changes observed in completed devices upon post-deposition "treatments." This work may help reduce the 
need for or possibly eliminate such treatment steps in a module fabrication process, by directly incorporating observed beneficial aspects into the core deposition processes.

All of the above work is supported by a standardized solar cell evaluation procedure established at Colorado State University. A comprehensive solar cell modeling effort is provided by Purdue University, which is developing a general solar cell model called "ADEPT." An early version of the model was released in 1992 to groups desiring modeling support. Other groups have, however, elected to use less comprehensive models (e.g., PC-1D) or developed their own simple solar cell models. Many collaborative efforts are established among the fundamental Poly Thin Film subcontractors, and others involve very active participation by NREL in-house researchers (see in-house summaries, below), PV companies, and international groups.

Because of previous stability problems with thin-film PV cells and modules, NREL is encouraging subcontractors to investigate device stability. Two types of instability phenomena have been reported for thin film CdTe and CIS cells. A small, relatively fast, and completely reversible change in the performance depends on the voltage or illumination history of the cells. Normally, the performance of the cells improves as they are being illuminated. As a consequence, measurements using pulsed solar simulators will under-read performance. Long-term, non-reversible degradations have also been reported. In the case of thin film CIS modules, these degradations are sometimes associated with poor adhesion between the CIS and the Mo-coated glass substrate. This problem is currently investigated by a number of subcontractors. In the case of thin film CdTe cells, long-term degradation is associated with a loss in FF and an increase in series resistance of the junction, although in a few isolated cases, cell performance has also been reported to improve as cells aged. In addition, moisture may lead to irreversible corrosion. It is hoped that the latter effect can be eliminated by appropriate cell encapsulation schemes. The series resistance problem is commonly believed to be a contact problem. This issue is somewhat uncertain because the further application of post-deposition "treatments" may, at times, improve the deteriorated contacts again. An encouraging note is that some unencapsulated thin film CdTe solar cells, including those with efficiency $\approx 15 \%$, have shown stable performance for limited periods (about three months testing, to-date).

\section{CIS Task at NREL}

The NREL in-house CIS task pursues short-term and long-term goals. For the short-term, we emphasize ongoing improved conversion efficiency of the $\mathrm{ZnO} / \mathrm{CdS} / \mathrm{CuInSe} \mathrm{e}_{2}$ solar cell. For the long-term, we contribute toward advancing the technology base by studying the fabrication processes of the different materials pertinent to the solar cell, and by understanding material properties and their relevance to solar cell performance.

There exist several obstacles to the introduction of the CIS technology to the marketplace. They include issues such as reproducibility, large area spatial uniformity, adhesion, and hence, module conversion efficiency. We believe all of these are related to the reaction 


\section{Polycrystalline thin Films FY 1992 Project Report}

NRET/TP-413-5270

DE93 000070

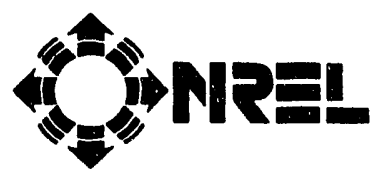

National Renewable Energy Laboratory 1617 Cole Boulevard Golden, Colorado 80401-3393

A Division of Midwest Research Institute Operated for the U.S. Department of Energy under Contract No. DE-AC02-83CH10093

January 1993

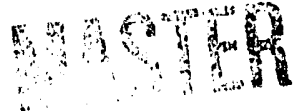




\section{NOTICE}

This report was prepared as an account of work sponsored by an agency of the United States government. Neither the United States government nor any agency thereof, nor any of their employees, makes any warranty, express or implied, or assumes any legal liability or responsibility for the accuracy, completeness, or usefulness of any information, apparatus, product, or process disclosed, or represents that its use would not infringe privately owned rights. Reference herein to any specific commercial product, process, or service by trade name, trademark, manufacturer, or otherwise does not necessarily constitute or imply its endorsement, recommendation, or favoring by the United States government or any agency thereof. The views and opinions of authors expressed herein do not necessarily state or reflect those of the United States govemment or any agency thereof.

Printed in the United States of America

Available from:

National Technical Information Service

U.S. Department of Commerce

5285 Port Royal Road

Springfield, VA 22161

Price: Microfiche A01

Printed Copy $\mathrm{AOS}$

Codes are used for pricing all publications. The code is determined by the number of pages in the publication. Information pertaining to the pricing codes can be found in the current issue of the following publications which are generally available in most libraries: Energy Research Abstracts (ERA); Government Reports Announcements and Index. (GRA and I); Scientific and Technical Abstract Reports (STAR); and publication NTIS-PR-360 available from NTIS at the above address. 


\title{
POLYCRYSTALLINE THIN FILMS FY92 PROJECT REPORT
}

\author{
K. Zweibel, Project Manager (editor)
}

\section{INTRODUCTION}

What are polycrystalline thin films and why do we focus about $\$ 10$ million of Federal funds annually on their development?

The purpose of the DOE/NREL PV Program is to facilitate the development of PV that can be used on a large enough scale to produce a significant amount of energy in the US and worldwide. The PV technologies under the Polycrystalline Thin Film umbrella are among the most exciting 'next-generation' options for achieving this goal. Over the last fifteen years, cell-level progress has been steady, with laboratory cell efficiencies reaching levels (15\% to $16 \%$ ) unheard of for thin films (Figure 1). This progress, combined with the potentially inexpensive methods used to make these cells, has attracted significant commercial interest from US and intemational companies. Among the companies now committed to commercializing polycrystalline thin films are AstroPower, BP Solar, Siemens Solar, Matsushita, Solar Cells Inc., Golden Photon, Energy PV, Intemational Solar Electric Technologies, Martin Marietta, and Solarex. The NREL/DOE program is designed to support the efforts of US companies through cost-shared subcontracts (called 'govemment/industry partnerships') that we manage and fund (see Table 1), and through collaborative technology development work between industry, universities, and our laboratory. About $60 \%$ of our Project funding is devoted to subcontracts with industry and with US universities.

During the last few years, much of the focus of our Project has switched from cell-level issues to issues conceming larger-area devices (submodules and modules). The companies that are developing polycrystalline thin films have all moved into a precommercial stage in which their concerns are process and manufacturability related. Table 2 is a summary of the state-of-the-art in submodule and module efficiencies for the key polycrystalline thin films. These modules represent the base upon which commercial products will be developed. In many cases, the efficiences of the modules in Table 2 far surpass those of any other thin film at those sizes.

As represented by the trends in Figure 1 (cell efficiencies) and the accomplishments of Table 2 (module sizes/efficiencies), the Polycrystalline Thin Films Project has a history of success. We believe that we are on the right path towards making new PV technologies a commercial reality. This report summarizes the activities and results of our last fiscal year, FY1992 (October 1991 - September 1992). It is organized by our main activities: our subcontracts program and our in-house technology development efforts in copper indium diselenide, cadmium telluride, and in materials and device characterization and analysis.

\section{POLYCRYSTALLINE THIN FIMM SUBCONTRACTS}

The polycrystalline thin film subcontract task supports research and development in three thin film technologies, namely, cadmium telluride (CdTe), copper indium diselenide (CIS, $\mathrm{CuInSe}_{2}$ ), and silicon-film (Si-Film) on low-cost substrates. The subcontracted research is divided into two areas, government/industry partnerships and university research. There 


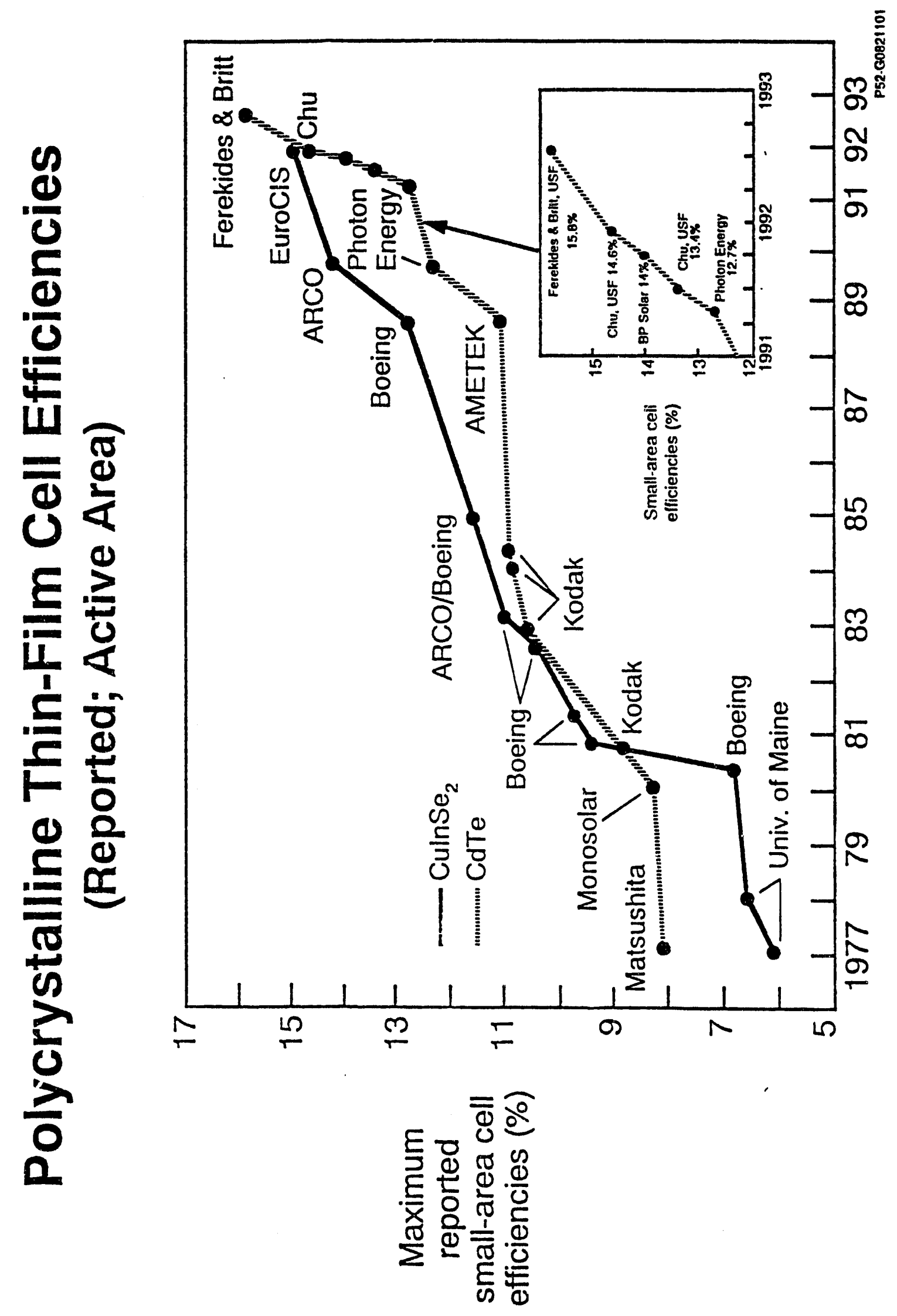




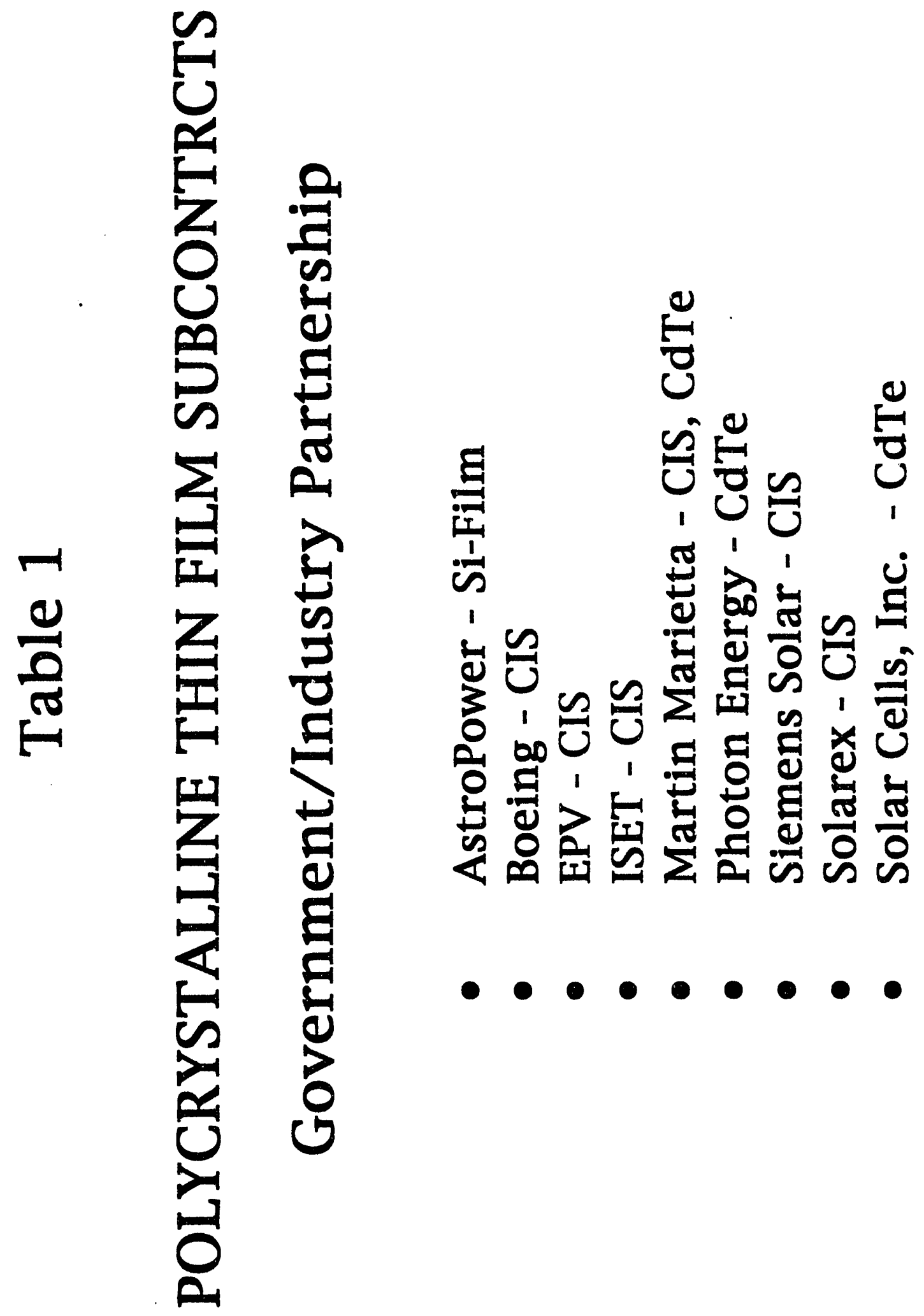




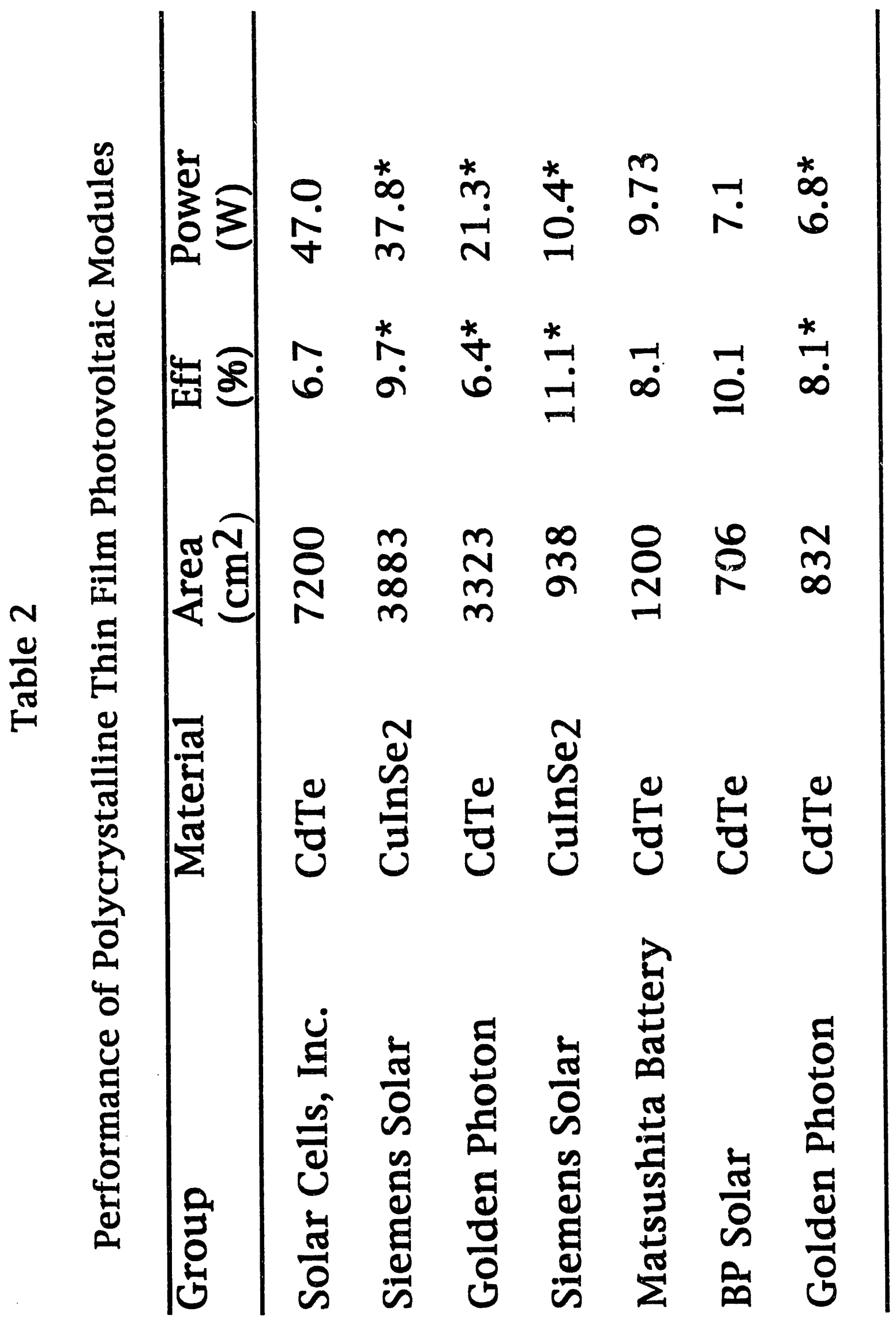


were nine industrial groups supported during FY92, including multinationals and small businesses, and ten university groups. Six of the university groups were winners in a recently concluded Letter of Interest (LOI) competition. Two university groups were selected as the first to be named University Centers of Excellence for Photovoltaic Research and Education by the Department of Energy.

\section{Government/Industry Partnerships}

As part of our government/industry partnership programs, nine groups were actively involved in the R\&D of polycrystalline thin films. This included both multinationals and small businesses. There were six groups working on CIS, two in CdTe and one in SiFilm. The various industrial subcontractors were given in Table 1, and the status of CIS and $\mathrm{CdTe}$ module performance was given in Table 2.

Substantial technical progress occurred in the area of thin film CdTe technology. Large area module efficiencies were improved by two groups. Photon Energy, Inc. (PEI) of El Paso, TX, improved the performance of their 4- $\mathrm{ft}^{2}$ thin film CdTe module to an aperturearea efficiency of $6.3 \%$ with a power output of $21 \mathrm{~W}$ (verified by NREL). Their modules are undergoing various reliability tests at PEI and NREL using several encapsulation schemes. The most effective encapsulation thus far has been glass-to-glass packaging. Further improvements are still needed to assure long-term outdoor performance.

More dramatic progress was made by Solar Cells, Inc. (SCI) of Toledo, OH. In little over a year after becoming one of our industrial partners, an $8-\mathrm{ft}^{2}$ thin film CdTe module with a reported aperture-area efficiency of $6.7 \%$ and a power output of $47 \mathrm{~W}$ was fabricated. SCI uses an extremely rapid deposition method in which the semiconductor layers (CdS, CdTe) are deposited over large areas in one minute. This could significantly reduce manufacturing costs. SCI is aggressively pursuing several encapsulation schemes for their thin film modules. Their near-term plans are to use a glass-to-glass encapsulant scheme, while long-term plans are to use a spray-on encapsulant to reduce the unit module cost by eliminating one piece of glass. SCI will be delivering a $1 \mathrm{~kW}$ system to NREL in FY93 as part of the PVUSA EMT-3 project.

Additionally, the thin film CdTe industrial infrastructure was bolstered by the entry of another multinational. On September 19, 1992, Adolph Coors Company, through its subsidiary Golden Technologies, purchased Photon Energy, Inc. The new company, Golden Photon, is headquartered in Golden, CO. New deposition equipment is being added to their facilities in El Paso, TX. Golden Photon expects to enter the market with a selling price (not manufacturing cost) of $\$ 3.00$ to $\$ 3.50$ per watt, with further price reductions as manufacturing capacities are increased to $10 \mathrm{MW}$ in Golden, CO by 1996.

The progress in thin film CIS technology has been mixed. Siemens Solar Inc. (SSI), the technology leader, faltered in its effort toward CIS commercialization when it canceled delivery of PVUSA modules. Their recent focus has been on their single-crystal silicon business. However, a 4- $\mathrm{ft}^{2}$ thin film CIS module with an aperture-area efficiency of $9.7 \%$ and a power output of $37.8 \mathrm{~W}$ has been verified by NREL. SSI published data showing 
that their average yield peaks at an aperture-area efficiency of $8 \%(33 \mathrm{~W})$. To put this number in perspective, all a-Si commercial modules are less that $6 \%$ efficient (APS, Solarex, Siemens Solar-Europe, USSC). Stability data on thin film CIS modules tested outdoors remains encouraging. Two $1-\mathrm{ft}^{2}$ thin film CIS modules being tested outdoors at NREL show almost no change in performance after four years of testing, while several 4- $\mathrm{ft}^{2}$ CIS modules also being tested at NREL for about a year are unchanged.

ISET has fabricated their first thin film CIS prototype submodules with reported power outputs in the range of 2.5 to $4.0 \mathrm{~W}$. The submodules were monolithically integrated using laser and mechanical scribing. More importantly, ISET has reached an active-area efficiency of $11 \%$ for small area devices using a nonvacuum method of depositing Cu-In. This proprietary technique is a relatively inexpensive method as compared to the conventional sputtering technique and could turn out to be one of the seminal technical achievements of the year if it is followed with prototype module development and manufacturing.

We have several other industrial partners. Martin Marietta (MM) has successfully installed equipment capable of handling 1- $\mathrm{ft}^{2}$ glass substrates. An innovative technique known as rotating cylindrical magnetron sputtering is being used to deposit the precursor $\mathrm{Cu}$-In. Small cells with total-area efficiencies near $8.5 \%$ have been fabricated thus far. MM has successfully leveraged the DOE/NREL subcontract to obtain other sources of funding. Solarex has achieved on active-area efficiency of $10.2 \%$ for a small-area cell and has made some early prototype submodules. In their process, the $\mathrm{Cu}$-In are deposited by sputtering followed by Se deposition by evaporation. Stoichiometric CIS is formed after a heat treatment in nitrogen at $400 \mathrm{C}$. Energy Photovoltaics (EPV) has fabricated a thin film CIS solar cell with an efficiency of 9.2\%. Like Solarex, EPV has made some early prototype thin film CIS modules up to $1-\mathrm{ft}^{2}$. Boeing, which was involved in cell research, has fabricated the world's highest total-area efficiency CIS-based cell (13.7\%) using CIGS (verified by NREL). AstroPower has been limited in their device performance by the inclusion of impurities both from the ceramic substrates and silicon feedstocks. Typical diffusion lengths are about $10 \mu \mathrm{m}$.

\section{University Research}

1992 has been an important year for progress in polycrystalline thin film solar cell efficiencies. Much of our groundbreaking work was done by universities. New world record efficiencies were obtained for thin film CdTe solar cells (two 15.8\% solar cells made at the University of South Florida, USF) as well as for thin film CIS solar cells (14.8\% active-area efficiency by the Euro-CIS university consortium) ${ }^{1}$. Very promising results were also obtained with quaternary CIS derived compounds, specifically sulphur (a reported $15.2 \%$ active area efficiency by the Euro-CIS university consortium) $)^{1}$, and gallium alloys (14.3\% active area efficiency, Boeing). Two university groups, namely,

1

Not NREL funded. 
Institute of Energy Conversion (IEC) at the University of Delaware and Georgia Institute of Technology (GIT), were declared "University Centers of Excellence for Photovoltaic Research and Education" by J. Michael Davis, Assistant Secretary, Conversation and Renewable Energy, Department of Energy.

It is of interest to note that fundamental research institutions themselves contributed a great deal towards achieving new efficiency records and, in many instances, completely fabricated high efficiency devices without the help of commercial companies. A number of relatively small university groups are experimentally equipped to prepare state-of-theart devices. Relatively little is known about the material properties of the poly-thin film materials. NREL, at the end of FY92, has ten university subcontracts in force to (1) achieve cells with even higher efficiencies, (2) better characterize the layers needed for the fabrication of such cells, (3) better understand the mechanisms providing opportunities for improved cell performance through measurements and computer modeling and simulations, and (4) investigate alternate methods of material preparation of these materials.

In the second half of 1991, 35 responses to a Letter of Interest "University Research on Polycrystalline Thin Film Photovoltaics" issued by NREL were evaluated and ranked. In FY92, six 3-year phased subcontracts were subsequently awarded. In addition, NREL funded four additional fundamental subcontracts under its Polycrystalline Thin-Film PV Program. Of these ten subcontracts, 2 groups focus on optimization of thin film CdTe solar cells and materials, 3 groups focus on thin film CIS cells and materials, 3 groups work with both types of cells and materials, and 2 groups provide standardized cell analyses and computer modeling for both types of solar cells. Table 3 lists these individual groups and indicates the specific issues addressed under the subcontracts.

Presently, various thin-film deposition techniques are used to prepare high-efficiency solar cells with CdTe and CIS, e.g., sputtering, co-evaporation, close-spaced sublimation, rapid thermal processing, chemical solution growth, spray deposition, and screen printing. Some of these techniques are more easily scalable than others. Both thin film CdTe and CIS solar cells commonly use $\mathrm{CdS}$ as the heterojunction partner. The highest efficiencies to date were achieved in the following configurations: glass $/ \mathrm{SnO}_{2} / \mathrm{CdS} / \mathrm{CdTe} / \mathrm{doped}$ graphite paste, where the $\mathrm{CdTe}$ is deposited by close-space sublimation, and glass/Mo/CIS (graded $\mathrm{Cu}$ content)/CdS/ZnO (double layer), where the CIS layer was produced by coevaporation. It may be of interest to note that both types of cells used CdS layers deposited from a chemical solution. Cell optimization requires that the CdS layer be kept as thin as possible. This has not only resulted in higher short-circuit current densities (which are expected because optical absurption losses in the CdS are minimized) but also in higher open-circuit voltages for such solar cells (the mechanism for higher voltages is not understood). However, the absorber-layer deposition process does not appear paramount for the achievement of high efficiencies; and for both materials a variety of deposition techniques (and combinations thereof in the fabrication of a completed cell) have resulted in cells with efficiencies $>10 \%$.

It is of some value to identify which mechanisms (e.g., junction-recombination, 


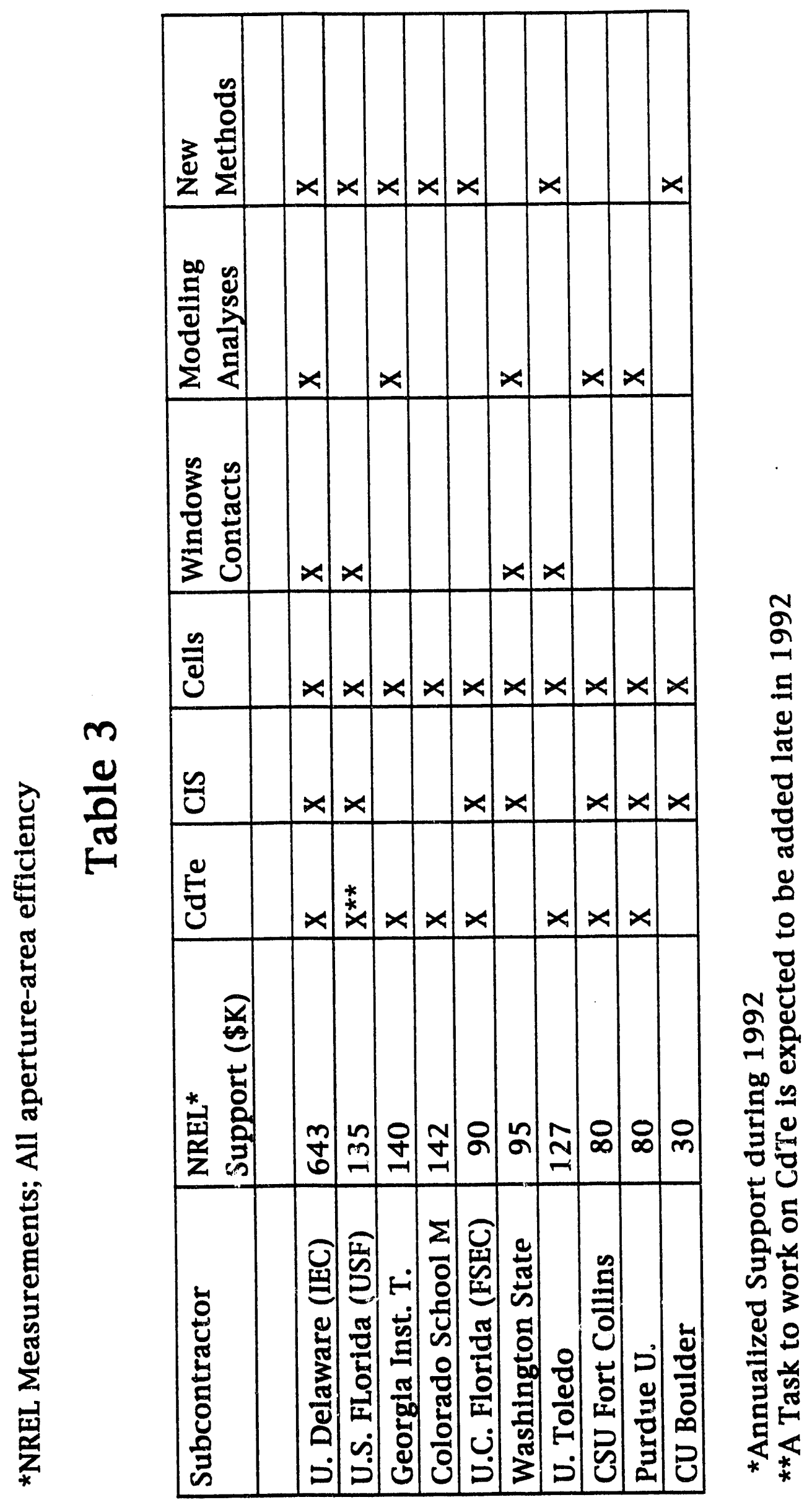


recombination in the absorber, incomplete collection limited by transport properties and/or non-optimized electric field distributions) truly account for the losses in each cell and cause non-ideal performance. The identification of such mechanisms is impeded by (1) lack of knowledge of the electronic properties of each layer, (2) ambiguity of solar cell models requiring many input parameters which are known only within some uncertainty, and (3) the possibility of interdiffusion when different layers are deposited on top of each other during cell fabrication. Especially the performance of thin film CdTe solar cells can be often substantially improved by exposing these cells to post-deposition "treatments" (e.g., a $400 \mathrm{C}$ anneal step in an oxygen acmosphere after the cell was dipped into a $\mathrm{CdCl}$ solution). Only crude speculative models have been proposed to-date to describe the effects of such treatments. All NREL subcontractors, guided by the quest to prepare high-efficiency solar cells, are actively analyzing these phenomena to be able to achieve better quantitative understanding of the electronic properties of their devices. Such improved understanding is critical to overcome problems that are encountered when cell fabrication processes are scaled-up to produce large-area PV modules with high performance and high production yields.

The experimental work of most of our fundamental subcontractors can largely be characterized as being driven by material preparation efforts. In the case of CIS, it is realized that the co-evaporation method, which has yielded cells with high conversion efficiency, may not be ideal because of scale-up difficulties. The other method of sputterdepositing a $\mathrm{Cu}$-In precursor and then "selenizing" the precursor with hydrogen selenide gas may limit production rates (selenization requires time) and involves highly toxic $\mathrm{H}_{2} \mathrm{Se}$ gas. A comparison of different selenization processes was carried out at IEC at the University of Delaware. The other groups use $\mathrm{Cu}$-In or CIS precursors prepared by physical vapor deposition methods, which are later reacted (by annealing) into CIS. One group (CU-Boulder) is investigating the use of rapid thermal processing for this purpose. All research groups prepare actual solar cells, sometimes in collaborative efforts. At the same time, the research groups have various material characterization efforts available to them which should lead to better characterization of the electronic properties of the layers produced, and a correlation with solar cell parameters. Another specific topic for thin film CIS solar cells is an attempt to replace the CdS emitter, because of the following benefits: (1) market related issues associated with cadmium, (2) possible elimination of a layer or process step, and (3) possible enhancements of the open-circuit voltage. Washington State University (with help from Siemens Solar and ISET) is investigating ZnSe-based window layers with some early success.

Several universities are engaged in thin film CdTe research. Close-snaced sublimation and laser ablation deposition are carried out at USF and University of Toledo, respectively. MOCVD deposition and rapid thermal annealing are used at GIT. Physical vapor deposition methods are used at IEC and at FSEC. Colorado School of Mines pursues deposition from chemical electrolytes. Again, all subcontractors have or will fabricate completed solar cells, sometimes in collaborative efforts. They apply their specialized material characterization capabilities to correlate material parameters and device performance. One area of attention is to identify the changes observed in completed devices upon post-deposition "treatments." This work may help reduce the 
need for or possibly eliminate such treatment steps in a module fabrication process, by directly incorporating observed beneficial aspects into the core deposition processes.

All of the above work is supported by a standardized solar cell evaluation procedure established at Colorado State University. A comprehensive solar cell modeling effort is provided by Purdue University, which is developing a general solar cell model called "ADEPT." An early version of the model was released in 1992 to groups desiring modeling support. Other groups have, however, elected to use less comprehensive models (e.g., PC-1D) or developed their own simple solar cell models. Many collaborative efforts are established among the fundamental Poly Thin Film subcontractors, and others involve very active participation by NREL in-house researchers (see in-house summaries, below), PV companies, and international groups.

Because of previous stability problems with thin-film PV cells and modules, NREL is encouraging subcontractors to investigate device stability. Two types of instability phenomena have been reported for thin film CdTe and CIS cells. A small, relatively fast, and completely reversible change in the performance depends on the voltage or illumination history of the cells. Normally, the performance of the cells improves as they are being illuminated. As a consequence, measurements using pulsed solar simulators will under-read performance. Long-term, non-reversible degradations have also been reported. In the case of thin film CIS modules, these degradations are sometimes associated with poor adhesion between the CIS and the Mo-coated glass substrate. This problem is currently investigated by a number of subcontractors. In the case of thin film CdTe cells, long-term degradation is associated with a loss in FF and an increase in series resistance of the junction, although in a few isolated cases, cell performance has also been reported to improve as cells aged. In addition, moisture may lead to irreversible corrosion. It is hoped that the latter effect can be eliminated by appropriate cell encapsulation schemes. The series resistance problem is commonly believed to be a contact problem. This issue is somewhat uncertain because the further application of post-deposition "treatments" may, at times, improve the deteriorated contacts again. An encouraging note is that some unencapsulated thin film CdTe solar cells, including those with efficiency $\approx 15 \%$, have shown stable performance for limited periods (about three months testing, to-date).

\section{CIS Task at NREL}

The NREL in-house CIS task pursues short-term and long-term goals. For the short-term, we emphasize ongoing improved conversion efficiency of the $\mathrm{ZnO} / \mathrm{CdS} / \mathrm{CuInSe} \mathrm{e}_{2}$ solar cell. For the long-term, we contribute toward advancing the technology base by studying the fabrication processes of the different materials pertinent to the solar cell, and by understanding material properties and their relevance to solar cell performance.

There exist several obstacles to the introduction of the CIS technology to the marketplace. They include issues such as reproducibility, large area spatial uniformity, adhesion, and hence, module conversion efficiency. We believe all of these are related to the reaction 
path from the elemental precursors to the formation of the thin-film compound.

In the past year, we completed a processing facility to fabricate CuInSe ${ }_{2}$ (CIS) by a variety of methods. Our aim is to explore the potential of each fabrication method to produce high efficiency devices, and to assess compatibility to manufacturing at low cost. The following is a list of these fabrication methods.

1. Selenization with Se vapor.

This process involves the deposition of $\mathrm{Cu} / \mathrm{In}$ metals on a glass/Mo substrate followed by annealing in Se vapor. Our current process is conducted in vacuum; however, we are modifying it to do the selenization at atmospheric pressures in order to minimize the role of vacuum. To-date, we have demonstrated active area efficiency $>10 \%$. We are focusing on adhesion and reproducibility issues.

2. Selenization with $\mathrm{H}_{2} \mathrm{Se}$ Gas

This process is similar to the above except that the selenization of the $\mathrm{Cu} / \mathrm{In}$ is done with $\mathrm{H}_{2} \mathrm{Se}$ gas. To date, others (e.g., Siemens Solar) have shown that this process yields the highest efficiencies $(\sim 14 \%)$ for a selenization process. However, the use of the $\mathrm{H}_{2} \mathrm{Se}$ toxic gas, and reproducibility, are issues of concem. We have constructed a laboratory to address these issues. This laboratory has been redesigned in the last year to address safety and environmental issues related to the process, and recently we have re-started this activity.

3. Co-evaporation from the elements.

This process involves the evaporation of the elements in vacuum to form the CIS thin film. Even though this process is not manufacturing-friendly (i.e., not scaleable and not cost-effective), it is our baseline process to produce high efficiency ( $>12 \%$ active area) devices and to establish a baseline for analyzing material properties. Evaporation has a quick turnaround in terms of exploring new device structures. It is the process we turn to when we need to begin efforts concerning novel ideas.

4. Rapid thermal processing (solid state selenization).

This process is by far the fastest and simplest. It involves depositing a stack of $\mathrm{Cu} / \mathrm{In} / \mathrm{Se}$ and annealing at high temperature for short periods of time. So far, it is the least explored because of the lack of in-situ control over composition, which renders making high efficiency devices somewhat difficult.

5. Device fabrication.

In addition to the CIS absorber, we, have established processes to fabricate the $\mathrm{CdS}$ heterojunction partner by chemical solution growth under slow as well as fast conditions, and the transparent $\mathrm{ZnO}$ window material. As an altemative to the $\mathrm{CdS}$, we have developed several non-Cd containing layers to investigate their potential as a replacement.

One or more of the above processes is being explored by different companies as their 
choice for commercialization. It is the function of our laboratory to make accessible to industry a comparison of these processes and the CIS material produced by them.

Our purpose is to compare processes and (1) to achieve high-efficiency devices, (2) to understand and improve materials and processes, and (3) to assist industry in solving problems hindering progress.

Using a matrix approach, we have developed a database which describes the properties of Cu/In precursors and selenized films as a sunction of processing conditions. From these experiments, we arrived at processing guidelines by which $\mathrm{CdS} / \mathrm{CuInSe}{ }_{2}$ solar cells with efficiencies $>10 \%$ can be fabricated. This ciatabase and guidelines for further progress toward lowi-cost fabrication are being disseminated to our industrial partner organizations.

We have also gained appreciable understanding of novel processing steps and material properties to formulate preliminary models for the materials and device requirements to push the frontier of this technology toward efficient and cost-effective modules. Communicating these results to industry is accomplished through site visits, exchange of data, and collaborative problem solving.

\section{CdTe Task at NREL}

\section{CdTe Solar Cells by Close Space Sublimation (CSS)}

CdTe thin film solar cells have become prominent due to outstanding cell results (15.8\%, USF) and the development of a manufacturing technology for large areas $\left(>6.5 \%\right.$ on $8 \mathrm{ft}^{2}$, $\mathrm{SCI})$. Research at USF has elevated the CdS/CdTe thin film solar cell to a high quality optoelectronic thin film device. However, there are significant differences between the laboratory technology and needed module production methods. We are addressing the issues needed to bridge that gap.

The CSS project was initiated in January 1992, with a view to develop expertise in cell fabrication and to find areas of collaboration and support for the CdTe industry. A new laboratory was established by April 1992. We were fortunate to be able to secure the services of the recently retired Professors Ting and Shirley Chu as consultants to accelerate our initial progress. In May 1992, a CdS/CdTe device of $11.3 \%$ efficiency was produced $\left(1.08 \mathrm{~cm}^{2}\right)$. At the time, this was a record for NREL-made thin film cells. The project has grown considerably, and our major activities can be summarized as follows:

- Development of solution growth technique for CdS thin films on large area (four inch by four inch) substrates.

- Understanding the unique optical properties of CdS films.

- Understanding the implications of using industrial grade substrates (e.g., soda lime glass) in terms of cell and module performance. 
- Fabricating $\geq 12 \%$ efficiency CdTe cells on soda lime glass (ongoing).

- Fabricating a large area $\left(100 \mathrm{~cm}^{2}\right) \mathrm{CdS}$ and CdTe denosition system and understanding problems associated with 'large area' thin film photovoltaics.

All of the above activities are currently underway. The project is designed to complement work at Solar Cells, Inc. and Golden Photon, Inc. Some examples of our collaborations are as follows:

- Solution grown CdS samples are made available to those that do not yet have their capability in this area, including SCI, GPI, and other NREL subcontractors; detailed growth procedures have been distributed to any group that desires to set up their own facility.

- Tin oxide coated glass samples from various vendors have been assembled, and a comprehensive study of the optical and electrical properties of the coatings has been conducted. The results show that the industrial coatings suffer from excessive losses. We are conducting this study and our cell fabrication work on commercial tin oxide-glass in order to assist industry to decide on a clear path toward commercialization. For example, industry has the choice of buying glasstin oxide or of depositing the tin oxide on glass themselves. Our studies are providing guidance for this complex but important decision.

\section{Electrical Contacts to p-type CdTe}

The high efficiencies that have been recently-demonstrated by several CdTe-based solar cells have promoted CdTe to the forefront of possible alternative for thin-film solar cell manufacturing. However, both industrial and academic researchers have acknowledged that, in order for the technology to remain viable as it nears the marketplace, a much more complete understanding of the quality and reliability of the CdTe electrical contact must be acquired. Because of the importance of this issue to the National PV program, and because NREL is likely better equipped than others to perform an in-depth contact study, an investigation of metal contacts to p-type CdTe has been initiated.

In the standard configuration of a CdTe solar cell, a low-resistance electrical contact must be made to p-type CdTe. However, because of a combination of several physical properties of the CdTe, the formation of this contact is not a trivial issue. Specifically, because of the nature of $\mathrm{CdTe}$, the energy required to move the electrical charge from within the CdTe into a typical metal contact is higher than one would like, resulting in significant contact resistance and subsequent power loss to the solar cell. Although over the years many techniques have been developed that can reduce contact losses, whether they can be advantageously incorporated in CdTe solar cell manufacturing processes is unknown.

The initial approach being used at NREL to study CdTe contacts is threefold. The first part of the project is aimed at studying whether typical semiconductor processes can be used to produce CdTe surfaces of appropriate quality for contacting. Examples of these 
processes include ion-beam cleaning and rf-biased etching. If successful, this direction of research will not only produce fundamental information on the electrical properties of the interface, but very possibly indicate methods to avoid the need to utilize timeconsuming chemical treatments (e.g., potassium dichromate etching) that are presently being used before metal contacts are applied. The second part of the research is to apply the processes noted above to If-sputter-deposited $\mathrm{CdTe}$ thin films to determine what fundamental process modifications may be warranted with this type of thin-film material. The third part of the research is simed at studying a typically-used contact interface player (e.g., Cu-doped ZnTe) to accurately determine if the incorporation of this sort of layer actually has overall technological advantages over simpler processes.

\section{rf-Sputter-Deposited CdTe Material and Devices}

It is noteworthy that high-quality CdTe solar cell devices have resulted from about ten vastly different CdTe deposition techniques. With this in mind, it is reasonable to investigate non-traditional deposition processes which may have production or manufacturing advantages. Because of its inherent high material utilization, controllability, and other properties, sputtering of CdTe is one such deposition process. To this end, and encouraged by preliminary investigations at NKEL during mid-FY91 to mid-FY92 that resulted in efficiencies exceeding 8\%, a project involving a study of rfsputtered CdTe material and solar cell devices was initiated. Presently, two sputtering systems have been modified to accommodate the physical and environmental considerations of sputtering CdTe. Likewise, engineering and procedural controls for the associated laboratories have been completed to enable pre- and post-deposition procedures to be safely performed on CdTe devices and diagnostic samples. Finally, several new pieces of apparatus have been constructed to enable in-vacuo and post-deposition heat treatments, and preliminary device characterization to be performed within the laboratory.

Following indications from the investigations mentioned above, studies during the second half of FY92 have focused on developing procedures for depositing CdTe with reproducible properties. For example, because stress in the as-deposited CdTe film was observed to be a fundamental limitation to the solar cell electrical parameters, of central importance has been the development of techniques and apparatus to study this problem. Due to the importance placed on increasing material and device reproducibility, progress has been steady. Presently, material from both deposition systems can produce nearly stress-free CdTe material. This material does not blister when annealed following the $\mathrm{CdCl}_{2}$ treatments. The severe shunting problems that were observed on earlier devices are avoided. Additionally, because of the substrate heating capability which has been added to one of the systems (and is being added to the other), the resulting as-deposited electrical resistivity of the CdTe is sufficiently low to enable both structural and compositional measurements to be accurately used.

In concert with the deposition studies, the development of post-deposition annealing procedures has progressed rapidly. The normal procedures that are presently used can produce blister-free films with grain sizes typically of 1-2 $\mu \mathrm{m}$ in diameter. Additionally, a novel investigation utilizing rapid thermal processing has resulted in post-annealed grain 
sizes exceeding $2 \mu \mathrm{m}$ in diameter (caused by a very short 90 -s heating cycle). It is believed that the results from this study may have considerable ramifications in production environments. The results from these, and other related studies, are presently being incorporated into our solar cell fabrication procedures.

Future directions for the rf-sputter-deposited CdTe material and device project will focus on developing procedures which are specifically suited to if-sputtering, and may also have considerable manufacturing advantages. One such process is the controlled incorporation of If-substrate biasing. In other material systems, the use of If biasing of the substrate has been found to not only reduce the substrate temperature required for a given set of material parameters (e.g., controlling the porosity of the deposit), but also to produce films of superior electrical and structural quality.

\section{The NREL Characterization Task}

The objective of this task under the Polycrystalline Project is to maintain and provide state-of-the-art chemical, compositional, structural, optical and microelectrical characterization of polycrystalline photovoltaic materials/devices in support of internal NREL research, DOE subcontracted research activities and the PV industry. This program uses time-resolved photoluminescence (PL), low-temperature PL, TEM, SEM, scanning Auger microscopy (SAM), $x$-ray and ultra-violet photoemission (XPS, UPS), and secondary ion mass spectrometry (SIMS) to support the investigation of various properties of thin-film polycrystalline photovoltaic materials and devices.

Industrial/subcontractor interactions included Energy Photovoltaics, Inc. (EPV), Photon Energy (now Golden Photon), Solar Cells, Inc., Institute of Energy Conversion (IEC), Solarex and Martin Marietta. Results provided by our laboratory have answered questions concerning the growth and processing of polycrystalline films and have allowed these subcontractors to further develop their capabilities.

\section{Specific highlights of our laboratory's accomplishments for FY 1992 are summarized as follows:}

Time-Resolved PL (TRPL) was extensively used to investigate the minority carrier lifetime of polycrystalline CdTe. This characterization work was done for both in-house and subcontract groups. These include the NREL program involving the collaboration with T. and S. Chu. The subcontract groups include Photon Energy, Solar Cell, Inc., and the Institute of Energy Conversion. It was observed on many samples that the film lifetime is often highly non-uniform. This non-uniformity is observed in the TRPL data as well as $\mathrm{V}_{\alpha}$ and $\mathrm{J}_{\mathrm{sc}}$ measurements. Work focused on the source of the non-uniformity. Recent work indicated greater uniformity on samples made at the University of South Florida, which, of course, are the best polycrystalline CdTe films made in the world.

Low temperature PL measurements were performed on over 700 samples of CdTe and $\mathrm{CuInSe}_{2}$ (CIS). These samples were again provided from the above sources. Our 
measurements resulted in band-gap information and indicated impurity levels by observation of the impurity band signals. In addition, the PL strength is a good indicator of polycrystailine quality.

XPS analysis was performed in order to compare the surface and bulk compositions of $\mathrm{CuInSe}_{2}$ thin films (which were purposely grown non-stoichiometric) and to look for phase separation. Some of the stable phases of $\mathrm{Cu}$-In-Se alloys include $\mathrm{Cu}_{2} \mathrm{Se}, \mathrm{In}_{2} \mathrm{Se}_{3}$, $\mathrm{CuInSe}_{2}$, and $\mathrm{Cu}_{1} \mathrm{In}_{3} \mathrm{Se}_{3}$ (1-3-5). Bulk compositions were determined with EDS, while surface compositions were determined with XPS. When the $\mathrm{Cu}$ to In ratio is less than unity, the bulk of the thin film is a mixture of $\mathrm{In}_{2} \mathrm{Se}_{3}$ and CuInSe$e_{2}$. However, a skin of $\mathrm{Cu}_{1} \mathrm{In}_{3} \mathrm{Se}_{5}$ forms on the surface of the thin films. A 1-3-5 skin was observed. On the $\mathrm{Cu}$ rich side, researchers measured samples in which the bulk $\mathrm{Cu}$ to In ratio was 2.89 . In principle, phase separation would lead one to expect that the surface would be a skin of $\mathrm{Cu}_{2} \mathrm{Se}$, with the $\mathrm{CuInSe}_{2}$ buried underneath. However, researchers observed a surface skin of excess $\mathrm{Cu}$ mixed with CuInSe, for a sample with a bulk $\mathrm{Cu}$ to In ratio of 2.89 . Accounting for the missing $\mathrm{Se}$ is still under investigation.

Additionally, the difference in the composition and electronic structure of the surface versus the bulk in polycrystalline CuInSe, films was investigated further using synchrotron radiation induced photoemission. This work was completed at the Alladin source, Synchrotron Radiation Center, University of Wisconsin-Madison.

XPS analysis has been employed to study the effects of chemical and ion beam etching of CdTe for surface passivation. CdTe substrates were etched in Br:MeOH prior to oxidation in order to provide a clean interface with superior transport characteristics. Additionally, CdTe substrates were subjected to a highly uniform low-power, low-energy AR ion beam $\left(0.5 \mathrm{keV}, 0.60 \mathrm{~mA} / \mathrm{cm}^{2}\right)$ exposure for various durations to improve surface properties prior to contact formation. XPS analyses prior to either etch procedure revealed a non-stoichiometric, Te-rich surface. XPS results for the etched surfaces indicated that both procedures yield clean stoichiometric surfaces suitable for producing ohmic contacts to p-type CdTe thin films.

Our Analytical Transmission and Scanning Electron Microscopy (TEM and SEM) facility was used for the characterization and analysis of the topographical, electrical, structural, compositional, and luminescent properties of CIS and CdTe devices and materials on a micron scale. A few typical FY92 applications were the following: (2) In developing the newly emerging, and record breaking, CSS CdTe, both USF and Solar Cells, Inc. required the location and spatial uniformity of the space charge region and recombination sites (defects) as a function of growth parameters. In both planar and cross-sectional modes, the inter- and intra-grain defects in their best cells were examined by NREL Materials Characterization Group (MCG) by both cathodoluminescence (CL) and electronbeam-induced current (EBIC) techniques for sources and patterns of device performance losses. The quite significant 3-dimensional variations in the CdTe film suggested the need for varying fabrication parameters to overcome nonuniformities. (2) Towards dramatically reducing fabrication costs, ISET has been successfully developing nonvacuum deposition of $\mathrm{Cu} / \mathrm{In}$ precursors. In collaboration, the MCG studied the 
topographical (growth dynamics) and electrical microcharacteristics of the resulting CIS in parallel with both ISET's sputtered and evaporated CIS precursors. The latter investigation revealed large variations in the composition of individual grains. This information helped ISET fine-tune their process for improved uniformity.

\section{CONCLUSIONS AND RECOMMENDATIONS}

We have seen substantial progress during FY92, but continued progress in polycrystalline thin films depends critically on resources. We are at a significant juncture wherein we may expect either continued progress or a we may risk serious loss of momentum. The reason for this is that progress now depends on scaling-up existing laboratory technologies, and this sort of scale-up requires significant corporate investment. More private funds are needed; and more risk exists for losing money. Unfortunately, our Project resources do not reflect this change of circumstances: we have had to cutback funds in $\mathrm{CuInSe}_{2}$ development rather than enhance them; and we have not had increased funds to add to our CdTe development to match the striking progress in that area. Thus, today, much depends on chance. We may be lucky and find that scaling-up these technologies is easier than previous experience (in which case, our funding strictures will not be critical). Or we may find that, as with other $\mathrm{PV}$, the transition to commercial products is fraught with birth pains and serious pitfalls. In which case, our loss of funding momentum could translate into serious technological setbacks, especially if key companies abort their commercialization efforts. We expect significant technical progress in FY93 and beyond; we expect to achieve significant cell and module efficiency milestones. But progress today has another dimension: capital risk. Due to DOE/NREL funding limits, we are less able to ameliorate that risk and thus less able to secure the future of these very promising technologies.

\section{ACKNOWLEDGMENTS}

The staff of the Polycrystalline Thin Film Project at NREL contributed their time and effort to writing this report. Both NREL and NREL-funded efforts nationwide contributed to the success of the Project during FY92. The US taxpayers are the source of the funds, and we wish to thank them and the various Federal decisionmakers (Congress and the Administration, especially DOE PV Division) for their support. Finally, we acknowledge the support of NREL management. 


\begin{tabular}{|c|c|c|c|}
\hline $\begin{array}{c}\text { Document Control } \\
\text { Page }\end{array}$ & $\begin{array}{l}\text { 1. NREL Report No. } \\
\text { NREL/TP-413-5270 }\end{array}$ & $\begin{array}{l}\text { 2. NTIS Accession No. } \\
\text { DE93000070 }\end{array}$ & 3. Recipient's Accession No. \\
\hline \multirow{2}{*}{\multicolumn{3}{|c|}{$\begin{array}{l}\text { 4. Title and Subtitle } \\
\text { Polycrystalline Thin Films FY } 1992 \text { Project Report }\end{array}$}} & $\begin{array}{l}\text { 5. Publication Date } \\
\text { January } 1993\end{array}$ \\
\hline & & & 6. \\
\hline \multicolumn{3}{|l|}{$\begin{array}{l}\text { 7. Author(s) } \\
\text { Ken Zweibel, Editor }\end{array}$} & 8. Performing Organization Rept. No. \\
\hline \multicolumn{3}{|c|}{ 9. Performing Organization Name and Address } & $\begin{array}{l}\text { 10. Project/Task/Work Unit No. } \\
\text { PV } 331101\end{array}$ \\
\hline \multicolumn{3}{|c|}{$\begin{array}{l}\text { NREL } \\
1617 \text { Cole Blvd. } \\
\text { Golden, Colorado } 80401.3393\end{array}$} & $\begin{array}{l}\text { 11. Contract }(C) \text { or Grant }(G) \text { No. } \\
\text { (C) } \\
\text { (G) }\end{array}$ \\
\hline \multirow{2}{*}{\multicolumn{3}{|c|}{$\begin{array}{l}\text { 12. Sponsoring Organization Name and Address } \\
\text { National Renewable Energy Laboratory } \\
1617 \text { Cole Blvd. } \\
\text { Golden, CO } 80401-3393\end{array}$}} & $\begin{array}{l}\text { 13. Type of Report \& Period Covered } \\
\text { Progress Report } \\
1 \text { October } 1991 \text { - } 30 \text { September } 1992 \\
\end{array}$ \\
\hline & & & 14. \\
\hline \multicolumn{4}{|c|}{ 15. Supplementary Notes } \\
\hline \multicolumn{4}{|c|}{$\begin{array}{l}\text { This report summarizes the activities and results of the Polycrystalline Thin Film Project during FY } 1992 \text {. The purpose of the } \\
\text { DOE/NREL PV Program is to facilitate the development of PV that can be used on a large enough scale to produce a } \\
\text { significant amount of energy in the U.S. and worldwide. The PV technologies under the Polycrystalline Thin Film project are } \\
\text { among the most exciting "next-generation" options for achieving this goal. Over the last } 15 \text { years, cell-level progress has been } \\
\text { steady, with laboratory cell efficiencies reaching levels of } 15 \% \text { to } 16 \% \text {. This progress, combined with potentially inexpensive } \\
\text { manufacturing methods, has attracted significant commerical interest from U.S. and international companies. The NREL/DOE } \\
\text { program is designed to support the efforts of U.S. companies through cost-shared subcontracts (called "government/industry } \\
\text { partnerships") that we manage and fund and through collaborative technology development work among industry, universities, } \\
\text { and our laboratory. }\end{array}$} \\
\hline \multicolumn{4}{|c|}{$\begin{array}{l}\text { 17. Document Analysis } \\
\text { a. Descriptors } \\
\text { polycrystalline thin film; photovoltaics ; solar cells } \\
\text { b. Identifiers/Open-Ended Terms }\end{array}$} \\
\hline \multirow{2}{*}{\multicolumn{2}{|c|}{$\begin{array}{l}\text { 18. Availability Statement } \\
\text { National Technical Information Service } \\
\text { U.S. Department of Commerce } \\
5285 \text { Port Royal Road } \\
\text { Springfield, VA } 22161\end{array}$}} & & $\begin{array}{l}\text { 19. No. of Pages } \\
20\end{array}$ \\
\hline & & & $\begin{array}{l}\text { 20. Price } \\
\text { A03 }\end{array}$ \\
\hline
\end{tabular}

Form No. 0069E (6-30-87) 

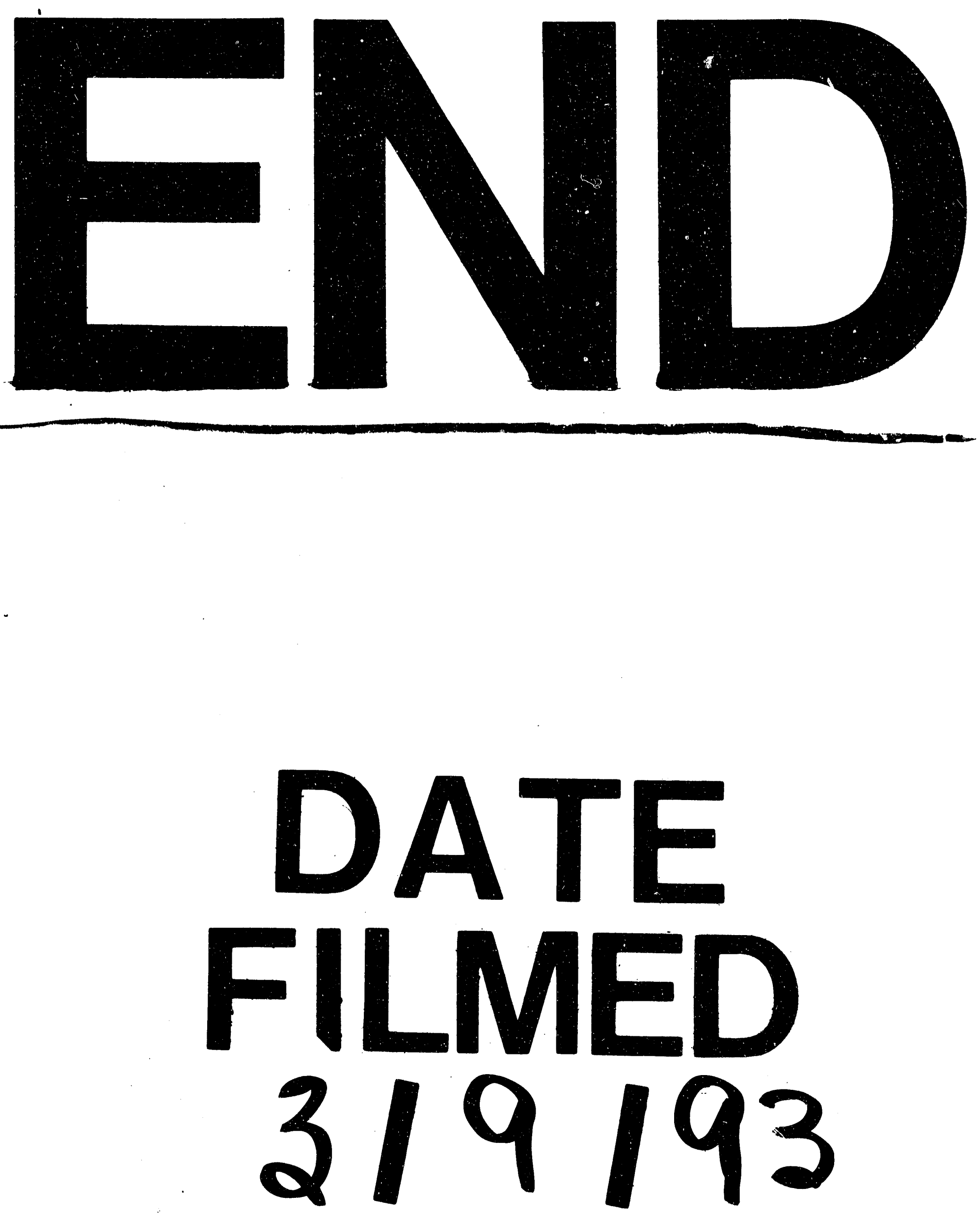
P
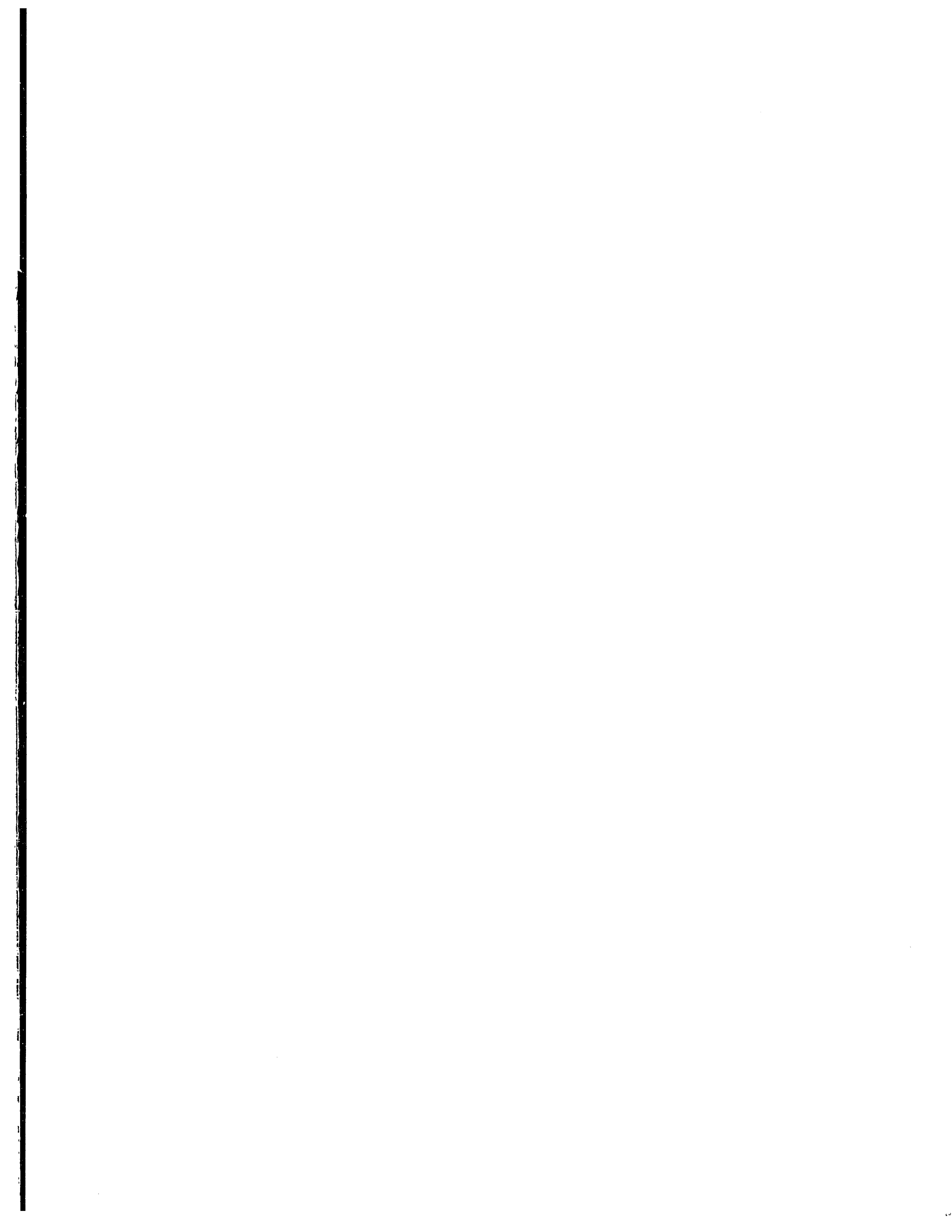